\title{
The Styles of Leadership and Project Success Relationship in the Construction Industry of Zambia
}

\author{
Tao Xiangxing ${ }^{1}$, Jonathan Musonda ${ }^{1}$
}

${ }^{1}$ Zhejiang University Of Science \& Technology

\begin{abstract}
Adequate leadership is a vital key to the successful performance of any firm or business, and it is much more important to the construction industry. The main objective of this paper is to explore the relationship between different leadership style practices and project success in the Zambian construction industry. The data used in this research were derived from both primary and secondary sources. The secondary data was collected via a detailed review of related literature. The primary data was collected through a structured questionnaire aimed at 150 project and construction managers in the Zambian construction industry. However, 110 questionnaires were received representing a $73 \%$ response rate. Data from the questionnaire were analyzed using SPSS 21.0 software. Correlation analysis was used to determine the relationship between leadership styles and project success. Likewise, the relationship between the different leadership styles and project successes in the Zambian construction industry was investigated using Pearson Product-moment Correlation Coefficient. Findings from the study revealed that there is a positive relationship between transactional leadership and project success. The results further revealed that there is no relationship between Laissez faire leadership style and construction project success. However, the study explores the relationship between leadership styles and project success in the Zambian construction industry. The study contributes to the body of knowledge of construction leadership by providing a robust background on construction leadership style practices of project and construction managers.
\end{abstract}

Keywords: Construction, Leadership Styles, Project Success, Relationship

\section{Introduction}

Good leadership helps any national state through times of challenges and further makes business organization to be successful. It also enables companies to fulfil their missions. Leadership is even more vital in the construction industry were success is measured by the projects being on time and within budget. On the contrary, the absence of leadership is equally dramatic in its effects. Without leadership, organizations move too slowly, stagnate, and lose their way. Thus, it is important to understand how leaders influence behaviour, change the course of events and overcome resistance. Moreover, it is also necessary to understand their leadership practices for project success. Hence, Ogunlana [1] states that, the success of a construction project depends on several factors, one of which is the competencies of the project leaders, their personalities, characteristics, skills and leadership styles, amongst others. All these impacts significantly on construction project outcomes. According to Müller and Turner [2], there is increasingly recognition that different types of projects require different methods for their management and leadership, as well as requiring management procedures tailored to meet the needs of the specific project.

It is important to note that the leader in the construction industry is responsible for the performance of the team and the achievement of their goals. Therefore, the construction leader who has good skills and management styles can expect good results from the team entrusted to them. Hence, this paper investigates the relationship between different leadership style practices and project success in the Zambian construction industry as it is very important to understand the leadership styles in the construction industry and their resultant effects on project successes.

2. Leadership in the Construction Industry It is also evident that the construction industry has a greater need for leadership than arguably any other industry. Many reasons support this notion and it is evident in the nature of the construction projects, and constructed products [3]. If one word could describe the essence of construction management it is responsibility since project leaders are responsible for all that happens in a construction project. This does not mean 
that the project leader should or could do everything associated with the project; but it does mean that they have ultimate responsibility for the project. In other words, the buck stops with the project leader. Since construction projects are large and technically complex and they involve a combination of specialized skills. Likewise, construction teams are not only large but are also multidisciplinary and the members are from several different construction disciplines and this makes good leadership style vital in this industry.

Leadership can be summed up as joint outcome of the leader's self-related cognitive information, personality traits, the underlying motives, and his understanding of operating situational variables [4]. Moreover, researchers on leadership have proposed a number of leadership styles such as democratic, autocratic, consultative, and joint decision making types, such as: transactional, transformational, and laissez faire [5]. Besides, in the construction industry, project and construction management were developed in construction and engineering fields in order to improve planning and cost controls [6].

Since, construction and project managers in the construction industry are responsible for the productivity of the project members; they should maintain cohesion in the project. Hence, they should be leaders who can motivate and inspire construction workers within the given projects. This is because leadership is considered to be good if it is designed to accomplish the goal or mission of an organization which is done through project team leading and project time managing, within budget, to a high quality, and with a satisfied customer [7]. Moreover, Price [8] stated that the simplest model of leadership works with three dimensions: vision, values and execution. If a business or a country does not have a clear vision of what is to be achieved, chances are it will be stuck in operational problems.

\subsection{Leadership Styles}

Leadership is a key factor for success in any activity that involves collaboration in a group (or groups) of people. In construction, leadership is even more essential [9]. Munns and Bjeimi [10] emphasize that the success or failure of project management is highly dependent on the project leaders. In an international study of leadership in the construction industry, Price [8] cited that all transformational factors such as: charisma, inspirational motivation, intellectual stimulation, and individualized consideration are important; but Price further informed that transactional factors, which are contingent reward, management- by-exception, active and passiveness were of great importance for the effectiveness of any leadership. Literature also reveals that well-perceived leadership style elements of construction professionals include inspirational motivation, idealized attributes, intellectual stimulation, idealized behaviour, contingent reward, and individualized consideration. According to Price [8], building professionals should adopt and promote the use of transformational leadership in their interactions with employees in order to realize greater employee performance and satisfaction.

\subsubsection{Transactional Leadership}

Transactional leadership underlies most leadership models, which focus on exchanges between leaders and followers [11]. It is an extrinsic-based motivation process by which leaders achieve their goals, while followers receive external rewards for job performance. An example of this type of leadership is the manager who offers rewards, such as promotions, extra pay, or time off, for employees who surpass their goals. Transactional leadership behaviours include interactive goal setting, contingent material reward, contingent personal reward and personal recognition [8].

\subsubsection{Charismatic Leadership}

Charismatic leadership can be described as a fire that ignites followers' energy and commitment, while producing results above and beyond the call of duty [8]. These effects are seen to have a higher probability of occurrence in stressful environments and situations where followers look to leaders to deliver them from their difficulties [11]. Generally, charismatic leadership works because it creates congruence between followers and their values and the organization's values and culture.

\subsubsection{Transformational Leadership}

Transformational leadership is basically a motivational process whereby leaders engage followers to create a connection that raises the effort and moral aspiration. Transformational leaders are attentive to the needs and motives of followers and help inspire them to develop into leaders [8]. This leadership style produces trust and satisfaction and working for a transformational leader can be a wonderful and uplifting experience. 


\subsubsection{Democratic leadership}

Leaders using this style provide direction, but allow the group to make its own decisions. Specifically, the leader encourages members to determine goals and procedures, and stimulates member's self-direction and self-actualization [12]. In addition, the democratic leader offers suggestions and reinforces member's ideas. The democratic style supports the teamwork method and always coaches and leads staff to achieve the organizational goals.

\subsubsection{Laissez-faire leadership}

According to Boonyachai [13], this leadership style allows the group to develop on its own decisions, as the leader has no real authority. Specifically, the leader answers questions, provides information, or gives reinforcement to the group. The subordinates of Laissez-Faire leaders have to seek other sources to support them in making final decisions.

\subsubsection{Authoritarian leadership}

This leadership style is the opposite of the Laissez-Faire leadership and Democratic leadership. Authoritarian leaders are commonly referred to as autocratic leaders. They provide clear expectations for what needs to be done, when it should be done, and how it should be done. There is also a clear divide between the leader and the followers. According to Evans [14], Authoritarian leadership sets agendas and determines the group's policies, assigns tasks to members, and makes decisions for the group without consulting subordinates. In the end, the leader takes responsibility for the group's progress, but accepts very few suggestions from the group. Rarely do the group members communicate with one another, but they communicate with the leader [14].

\subsection{Relationship between leadership characteristics and project success/failure}

Turner \& Pearce [15] were of the view that the leadership style and competencies' of leaders are key to successful performance in business; which have been confirmed by other scholars to have a correlation between these and the performance of organizations and companies. Additionally, Zhang [16] noted that the importance of project leadership to project success may be related to the types of project. Specifically, project complexity has been offered in the literature as having a possible moderating impact on the relationship between project leadership practices and success rates. According to Jarad [7], the team is equally important for project success. The collaboration within the team and the performance of each individual team member as well as the performance of the team as one unit are critical factors for project success. Without a performing team it is difficult to secure project success, and for a leader to have a performing team, the leaders have to ignite the fire of performance and set boundaries within the team for it to function. In addition, leading a project towards success requires the manager to get the work done by the team members efficiently and effectively. The entire process requires the leader to have a clear vision, clarity in reasoning, practical in scheduling and the ability to attract a talented and efficient team. This, together with the application of a leadership styles brings about project success.

\section{Research Methodology}

Research methodology considers the context of the research and the desired results in order to achieve meaningful research outcomes. Moreover, the selection of an appropriate research design involves several steps, beginning with identifying the problem, purpose of the study and in depth literature review. This research adopted a quantitative approach which involved the use of a questionnaire. Burns and Grove [17] describes quantitative research as a formal, systematic process that describes and test relationships and examines causes among variables. In addition, Polit and Hungler [18] were of the view that quantitative research is a survey to obtain information from a sample of people by means of self-report, whereby people respond to a sequence of questions posed to them by the researcher. The data used in this paper were derived from both primary and secondary sources. The primary data was obtained through the questionnaire survey method through the use of a purposive sample, targeted at the only the project and construction managers; while the secondary data was derived from the review of literature and archival records. The questionnaire survey method was decided upon for this study because of the following reasons: they require less time and energy to administer and they offer the possibility of anonymity because the respondent's names are not required on the completed questionnaires. The relationship between the different leadership styles and project success was investigated using Pearson product-moment correlation coefficient (Correlation analysis). Correlation analysis measures the relationship between two items, for example, a particular leadership style and project success. The resulting value (called the correlation coefficient) shows if changes in one item will result in changes in the other item [19]. 
Pearson correlation coefficient was utilized for this study to measure the relationship amongst the research variables (relationship between leadership style practices and project success).

However, before understanding correlation coefficient it is important to understand the importance of statistical significance testing (p-value). Pallant [19] informs that the p-value is the probability of obtaining a test statistic result of at least as extreme or as close to the one that was actually observed, assuming that the null hypothesis is true. Researchers often "reject the null hypothesis" when the p-value turns out to be less than a predetermined significance level, often between 0.05 or 0.01 . For this study, the p- value for the leadership style practices was benchmarked at 0.05 in order to obtain a statistics significance of the variables being studied. Also, the correlation coefficient (r-value) can range between \pm 1.0 . A coefficient of +1.0 is a "perfect positive correlation", meaning that changes in the independent item will result in an identical change in the dependent item (for example, a certain leadership style will result in project success). A coefficient of -1.0, a "perfect negative correlation," means that changes in the independent item will result in an identical change in the dependent item, but the change will be in the opposite direction. A coefficient of zero means there is no relationship between the two items and that a change in the independent item will have no effect in the dependent item [19]. In addition, a low correlation coefficient (for example, say less than \pm 0.30 ) suggests that the relationship between two items is weak or non-existent [20]. These correlations can also be translated as follows: high correlation: 0.5 to 1.0 or -0.5 to 1.0 ; medium correlation: 0.3 to 0.5 or -0.3 to 0.5 and no correlation: less than 0.3 . In relation to the study, correlation analysis was used to access the relationship between leadership style practices and project success.

The analysis for this paper was based on the collected questionnaires and from the 150 questionnaires sent out, 111 were received representing a $74 \%$ response rate. This was considered adequate for the analysis based on the assertion by Moser and Kalton [21] that the result of a survey could be considered as biased and of little value if the return rate is lower than 30-40\%. Also, any research based on measurement of variables must be concerned with the accuracy and dependability. A reliability coefficient demonstrates whether the survey instrument design was accurate in measuring the variables being studied if the items will yield interpretable statements about individual differences [22]. Hence, in order to obtain reliability for this study, the Cronbach Alpha was adopted. George and Shamas [23] informs that Cronbach's Alpha above 0.7 is acceptable for reliable analysis. Therefore, the description of reliabilities of all scales used in the study indicated a Cronbach Alpha of above 0.7, which met with the minimum standard of acceptability for reliability. Further, the data presentation and analysis for the research, made use of frequency distributions, percentages of all the respondents and correlation analysis.

\section{Findings and Discussions}

Based on the correlation analysis between the various leadership styles and construction project, it was observed from the findings that the Pearson correlation shows positive moderate significance between transactional leadership and project success $(\mathrm{r}=0.40$; $\mathrm{p}<0.01)$. This suggests that there is a relationship between transactional leadership and project success. This indicted that transactional leadership in the Zambian construction industry is more likely to have success in construction projects than any other leadership style. Furthermore, the findings revealed that the Pearson correlation shows strong positive correlation between transformational leadership and project success $(\mathrm{r}=0.50 ; \mathrm{p}<0.01)$, but not as significance as the transactional leadership style. This also suggests that there is a strong relationship between transformational leadership and success. Transformational leadership was the first ranked leadership style in the Zambian construction industry. Hence, there is a strong relationship between transformational and project success. This infers that construction transactional leaders are prone to have project success in the Zambian construction industry.

It was further observed from the findings, that the Pearson correlation shows a weak correlation between democratic leadership and project success $(r=0.34 ; p<0.01)$. This suggests that there is a low relationship between democratic leadership and project success in the construction industry. This means that democratic leaders are less likely to have project success in the Zambian construction industry. Findings also show no significance relationship between autocratic leadership and project success in the Zambian construction industry $(r=-0.05)$. Based on this finding, it is evident that autocratic 
leaders do not have successful project. In addition, there was no significant relationship between laissez faire leadership style and construction project success $(r=0.14)$. This suggests that there is no relationship between laissez faire leadership style and project success. However, further research is encouraged to understand fully the most likely to be a successful style of leadership.

Table 1: Relationship between different leadership styles and project success

\begin{tabular}{|c|c|c|}
\hline \multicolumn{2}{|l|}{ Leadership style } & PROJECT SUCCESS \\
\hline \multirow[t]{3}{*}{ Transactional Leadership } & $\begin{array}{l}\text { Pearson } \\
\text { Correlation }\end{array}$ & $.403 * *$ \\
\hline & Sig. (2-tailed) & .000 \\
\hline & $\mathrm{N}$ & 111 \\
\hline \multirow{3}{*}{$\begin{array}{l}\text { Transformational } \\
\text { Leadership }\end{array}$} & $\begin{array}{l}\text { Pearson } \\
\text { Correlation }\end{array}$ & $.501 * *$ \\
\hline & Sig. (2-tailed) & .000 \\
\hline & $\mathrm{N}$ & 111 \\
\hline \multirow[t]{3}{*}{ Democratic Leadership } & $\begin{array}{l}\text { Pearson } \\
\text { Correlation }\end{array}$ & $.342 * *$ \\
\hline & Sig. (2-tailed) & .000 \\
\hline & $\mathrm{N}$ & 111 \\
\hline \multirow[t]{3}{*}{ Autocratic Leadership } & $\begin{array}{l}\text { Pearson } \\
\text { Correlation }\end{array}$ & -.058 \\
\hline & Sig. (2-tailed) & .548 \\
\hline & $\mathrm{N}$ & 111 \\
\hline \multirow[t]{3}{*}{ Laissez faire Leadership } & $\begin{array}{l}\text { Pearson } \\
\text { Correlation }\end{array}$ & .145 \\
\hline & Sig. (2-tailed) & .128 \\
\hline & $\mathrm{N}$ & 111 \\
\hline
\end{tabular}

** Correlation is significant at the 0.01 level (2-tailed)

In order to ensure that construction leaders are successful, they are required to employ an adaptive approach to leadership. Stated differently, successful leaders should acquire a wide range of leadership styles or approaches, and successfully match the required style to a particular situation. A leader that only has one type of leadership style will only be successful in a situation demanding that specific leadership style; whereas a diverse range of styles will guarantee success because of the dynamics of the construction industry. Turner \& Pearce [15] indicated that leadership styles and competence is key to successful performance of construction firms, and other similar studies have confirmed a correlation between different leadership styles and construction performance. Additionally, Zhang [16] noted that the relationship between leadership styles and project success may depend on the type of project. However, regardless of the project type, leadership styles of the leaders plays a considerable part in project success.

\section{Conclusions}

The relationship between the different leadership style practices of construction and project managers towards project success in the Zambian construction industry was discussed. From the various leadership styles as studied by the research, it was evident that there is a strong relationship between transactional and transformational leadership styles and project success in the Zambian construction industry. It was specifically found in the study that transformational leadership style has significant relationships with project delivery. However, democratic leadership style showed a low relationship for project success. Findings further revealed that there was no relationship between autocratic leadership and project success in the Zambian construction industry and lastly, laissez fair also revealed no relationship for project success. The research findings of this study provide important contribution especially in the Zambian construction industry whereby it can provide some guidelines for construction and project managers to identify their leadership styles towards successful implementation and management of their projects in order to achieve project success. It is important to note that good leadership assist in the successful execution of projects.

\section{References}

1. Ogunlana, S., 2011. Factors and procedures in large construction projects in Vietnam, Engineering, Construction and Architectural Management, Vol. 11 No.6.

2. Muller, R., and Turner. R., 2007. Matching the project manager's leadership style to project type, International Journal of Project Management, Vol. 25, No. 1, pp. 21-32.

3. Hillebrandt, P. M., 2000. Economic Theory and the Construction Industry. 3rd Edition, Basingstoke: Macmillan.

4. Toor, S. R., and Ofori. G. (2008) 'Leadership for future construction industry: Agenda for authentic leadership', International Journal of Project Management, 26. (6.), pp. 620-630.

5. Bass, M., \& Avolio, J., 2004. Improving organizational effectiveness though transformational leadership, California: Thousand Oaks.

6. Arendse, J., 2013. Project management competency factors in the built environment. Masters Dissertation. Available from:

https://ujdigispace.uj.ac.za/bitstream/handle/10210/8588/ Arendse, \%20Jerome\%20R\%202013\%20Masters.pdf?sequ ence $=1$ (Accessed on 16/03/2014).

7. Jarad, G. H., 2012. 'The construction manager leading characteristics for the success of construction projects in the Gaza Strip' Master's Thesis, The Islamic university of Gaza

8. Price, J. J., 2009. The Conception and Operationalization of leadership in construction companies, Masters Degrees Thesis, UNISA.

9. Ogunlana, S., 2008. Performance and leadership outcome correlates of leadership styles and subordinate commitment' Engineering Construction and Architectural Management, Vol 15, no. 2, pp. 7-99

10. Munns A. K., \& Bjeirmi B.F., 1996. The role of 
project management in achieving project success'.

11. Northouse, P. G., 2000. Leadership theory and practice. 2nd ed. Thousand Oaks: Sage

12. Bartol, K., Tein, M. Mathew, G. \& Martin, D., 2003. Management: A Pacific Rim Focus enhanced edn. Sydney: McGraw-Hill.

13. Boonyachai, Y., 2011. An investigation of the leadership styles of middle managers in the Thai hotel industry using the MLQ (5X-Short Form) and Hofstede's Cultural Dimensions, DBA thesis, Southern Cross University, Lismore, NSW.

14. Evans, V. S., \& Evans A. L., 2002. Leadership workshop, Education journal, 123. (1.).

15. Turner, R. K. and Pearce, D. W. (2011) 'Sustainable economic development: economic and ethical principles. In Barbier, E. (ed), Economics and Ecology: New Frontiers and Sustainable Development. London: Chapman \& Hall.

16. Zhang, Z., 2009. Beyond genetic explanations for leadership: The moderating role of the social environment. Available from. Journal homepage: www.elsevier.com/locate/obhdp. Organizational Behavior and Human Decision Processes 110 (2009) $118-128$
17. Burns, N. \& Grooves, K. G., 1993. The practice of Nursing Research Conduct, Critique and Utilization. Second Edition, Philadelphia: WB Saunders Company.

18. Polit, D \& Hungler, B. P., 1993. Essentials of nursing research. Methods, appraisal and utilization. 3rd edition. Philadelphia: Lippincott.

19. Pallant, J., 2005. SPSS survival manual: A step by step guide to data analysis using SPSS, 2nd edition, ALLEN UNWIN

20. McBurney, D. H. \& White, T. L., 2007. Research Methods. 7th ed. Belmount, California: Thomson Wadsworth

21. Moser, C.A. and Kalton, G. (1971). Survey methods in social investigation. Heinemann Educational: UK.

22. Cronbach, L., 1951. Coefficient alpha and the internal structure of tests'. University of Illinois, Psychometrika.

23. George, O., \& Shamas, R., 2012. Leadership and Construction Industry Development in Developing Countries', Journal of Construction in Developing Countries, 1(2) 